\title{
KERETES PNEUMATIKUS PRÉS TERVEZÉSE
}

\author{
Pintér Márton András ${ }^{a}$, Borbély Tibor $^{b^{*}}$, Biczó Roland ${ }^{c}$ \\ a ELTE, Informatikai Kar, Savaria Mứszaki Intézet, Duális gépészmérnöki BSc, 4. évf. \\ ${ }^{b}$ ELTE, Informatikai Kar, Savaria Múszaki Intézet, egyetemi docens \\ ${ }^{b}$ Schaeffler Savaria Kft., okleveles gépészmérnök
}

\begin{abstract}
ABSZTRAKT
A gépkocsik súrlódó tengelykapcsolójának egyik legfontosabb alkatrésze a súrlódótárcsa. A különbözô belsô kialakítású (különbözô szerkezetú) súrlódóbetétek roncsolásos vizsgálatához próbatestek kivágására van szükség. Egy, a próbatestek alapanyagául szolgáló súrlódóbetét elôgyártmányok elkészítéshez szükséges keretes, pneumatikus múködtetésú prés fejlesztési folyamatát mutatja be a cikk, amely kitér a méretezés és a szilárdsági ellenôrzés kérdéseire is. A prés a próbatestekhez szükséges súrlódóbetét előgyártmányok készítésén kívül alkalmas a gyártásközi selejtek javítására, azaz utómunkázásra is.
\end{abstract}

Kulcsszavak: présgép, vizsgálati darabok, súrlódóbetét, utómunka

\section{Bevezetés}

A présgép megtervezése és elkészítése után a következő feladat szálerősítésủ kompozit betét mechanikai vizsgálata lesz. A végeselemes szimulációhoz létre kell hozni a kompozit merevségi mátrixát, amihez a kompozitból készített próbatestek mechanikai tulajdonságainak kimérésére van szükség. A vizsgálatokhoz adott orientációba rendezett szálakkal készülő elógyártmányra van szükség, hogy a mechanikai vizsgálatok során egytengelyư feszültségállapot jöjjön létre. Ez a feladat nehezen oldható meg a jelenleg gyártásban lévő présgéppel, mivel a két szerszámfél között nincs elég szabad hely, és az üzemi hômérséklete is magas. Ezért volt szükség a különböző szövési mintájú, száraz súrlódó szálerôsítésú kompozit-betét előgyártmányának elkészítésére alkalmas, kézi prés tervezésére, mely ezen kívül használható a sorozatgyártás utómunkázására, azaz a selejtszám csökkentésére is.

A feladat megoldásának első lépése a koncepciólista összeállítása és az optimális megoldás kiválasztása volt, majd a geometriai kialakítás és a szilárdsági ellenôrzés következett. Szakirodalmi áttekintésben vizsgáltuk a súrlódóbetét szokásos szerkezetét, kialakítását, gyártástechnológiáját. A polimerek alkalmazása ma már igen elterjedt, akár súrlódó elemekként is használatosak kiváló mechanikai és tribológiai tulajdonságaik miatt. A jármúiparban használt súrlódóbetétek egy része üvegvagy fémszál-erősítésû́ kompozit [1]. A kompozit olyan többfázisú, összetett erősítőanyagból és beágyazó anyagból álló anyagrendszer, amelyben a nagy szilárdságú és nagy rugalmassági modulusú erôsítőanyag és a szívós mátrix között jelentős deformáció és/vagy igénybevétel esetén is tartós adhéziós kapcsolat van [1].

A nagyobb teljesítményú motoroknál az élettartamra vonatkozó új előírások bonyolultabb tengelykapcsoló kialakításokat kívántak meg. Más fontos alkotóelemek mellett a súrlódóbetét a tengelykapcsoló szíve. A repedési fordulatszámra vonatkozó követelmények és így a súrlódó anyag szakítószilárdsága fontos kritérium a súrlódóbetét tervezésekor [2].

(C) ELTE, Informatikai Kar, Savaria Múszaki Intézet, 2020

*Kapcsolattartó: bt@inf.elte.hu

https://doi.org/10.37775/EIS.2020.1.7 
1. táblázat: Kiértékelés

\begin{tabular}{|c|c|c|c|c|c|c|c|c|}
\hline Kiválasztott koncepciók: & Gyárthatóság: & Szerelhetôség: & Ár: & Rugalmasság: & Szabályozhatóság: & Kezelhetốség: & Karbantarthatóság: & Össz pontszám 35-bôl \\
\hline 1.Koncepció & 4 & 4 & 2 & 4 & 3 & 5 & 4 & 26 \\
\hline 3.Koncepció & 2 & 2 & 4 & 3 & 3 & 5 & 1 & 20 \\
\hline 4.Koncepció & 5 & 5 & 4 & 5 & 5 & 4 & 5 & 33 \\
\hline 5.Koncepció & 3 & 4 & 2 & 3 & 5 & 4 & 2 & 23 \\
\hline 10.Koncepció & 5 & 5 & 3 & 4 & 5 & 4 & 4 & 30 \\
\hline \multirow{5}{*}{ Értékelési fokozatok: } & 1 Elfogadhatatlan & & & & & & & \\
\hline & 2 Rossz & & & & & & & \\
\hline & 3 Javitható & & & & & & & \\
\hline & 4 Elfogadható & & & & & & & \\
\hline & 5 Megfelelố & & & & & & & \\
\hline
\end{tabular}

\section{A présgép tervezésének a folyamata}

Elsôként meghatároztuk az összfunkciót: a gépnek alkalmasnak kell lennie a kezdeti adhézió létrehozására az előgyártmányban nyomással. Ezt követte a részfunkciók meghatározása, amelyek (a teljesség igénye nélkül): az alkatrészek közötti mechanikai kapcsolat létrehozása, a szerszám pozícionálása, a megfelelô szilárdságú alátámasztás létrehozása. Következô lépésben létrehoztunk egy 10 megoldásváltozatból álló koncepciólistát, amelynél sajátos jelöléseket alkalmaztunk, majd ezek közül választottunk ki ötöt, melyeket 7 szempont szerint értékeltünk. Az előzetesen kiválasztott koncepciókat kiértékelő táblázatot az 1. táblázat mutatja. A legjobbra értékelt két koncepcióról készült vázlatot az 1(a) és 1(b) ábra szemlélteti.

Az ábrázolt két megvalósítási lehetôség közül az 1(a) ábrán látható keretes prést választottuk, mivel ez könnyebben kivitelezhetô. A mechanikai méretezés első lépéseként felvettünk egy állandó keresztmetszetű keretszerkezetet, amelyet a 2. ábra szemléltet.

Mivel hat ismeretlen volt az egyensúlyi egyenletben, így a tartó határozatlan, amelyet Betti-tétellel oldottunk meg. A számítást követôen megkaptuk a reakcióeróket és a reakciónyomatékokat, amelyek alapján felrajzoltuk az állandó keresztmetszetú tartó nyomatéki ábráját (2. ábra).

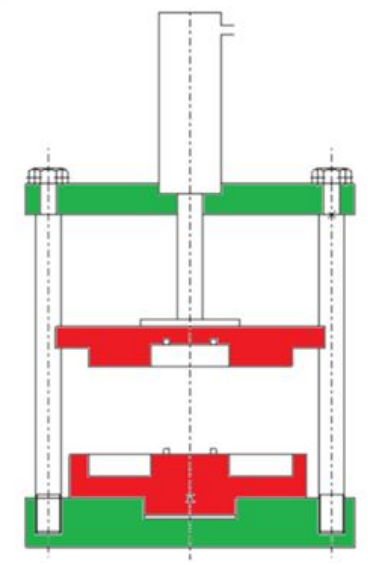

(a)

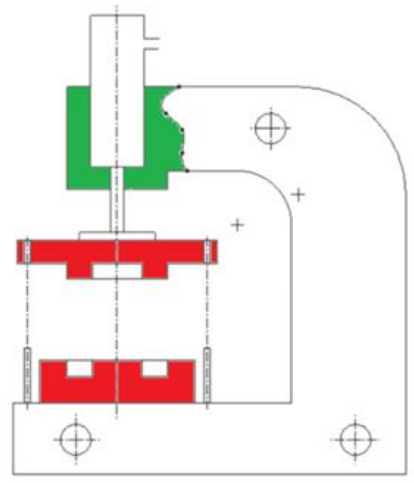

(b)

1. ábra: A legjobbra értékelt koncepciók vázlata: a) keretes prés, b) öntött házas prés 


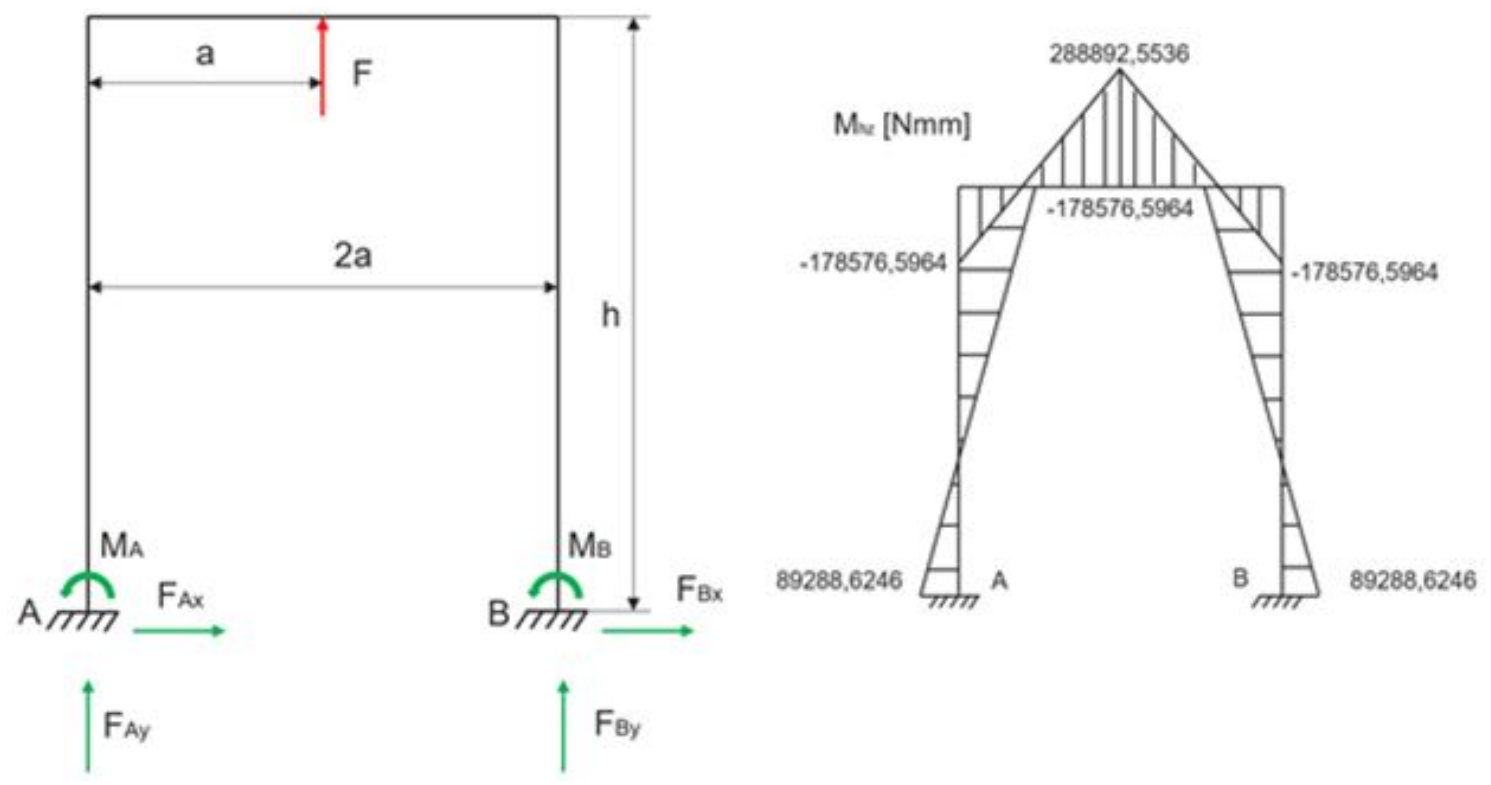

2. ábra: A keretszerkezet egyszerûsített vázlata a nyomatéki ábrával

Ezután a fellépố igénybevételek alapján meghatároztuk, melyik keresztmetszeteket kell nagyobb merevséggel ellátni. A legjobban igénybe vett elem a kereszttartó, ezért annak nagyobb hajlítómerevségúnek kell lennie, mint a tartóoszlopoknak. A következô lépés a prés CAD modelljének létrehozása, amelyhez a Creo Parametric II program használtuk. A berendezés háromdimenziós modellje a 3. ábrán látható.

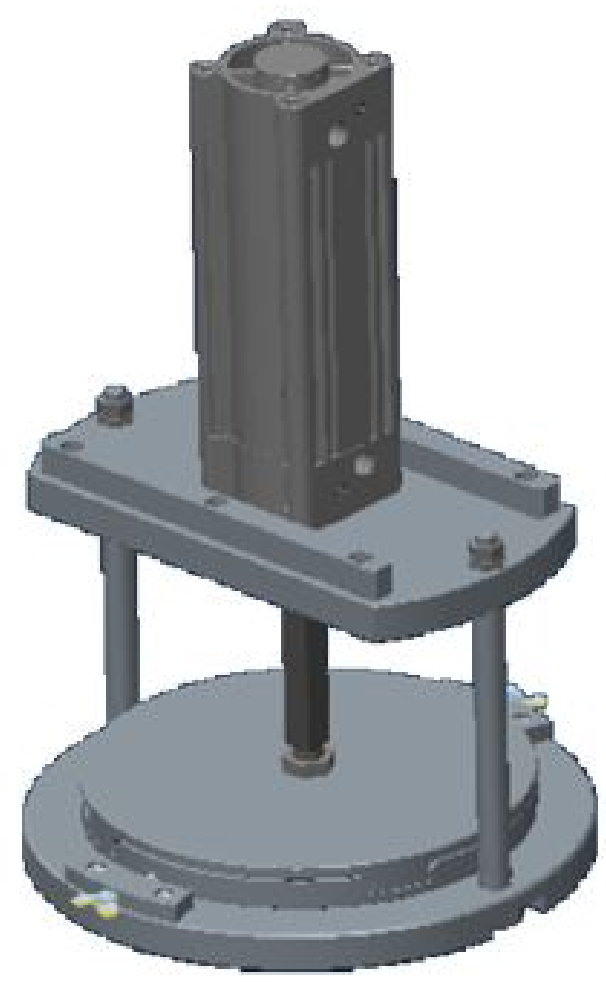

3. ábra: Présgép CAD modellje 


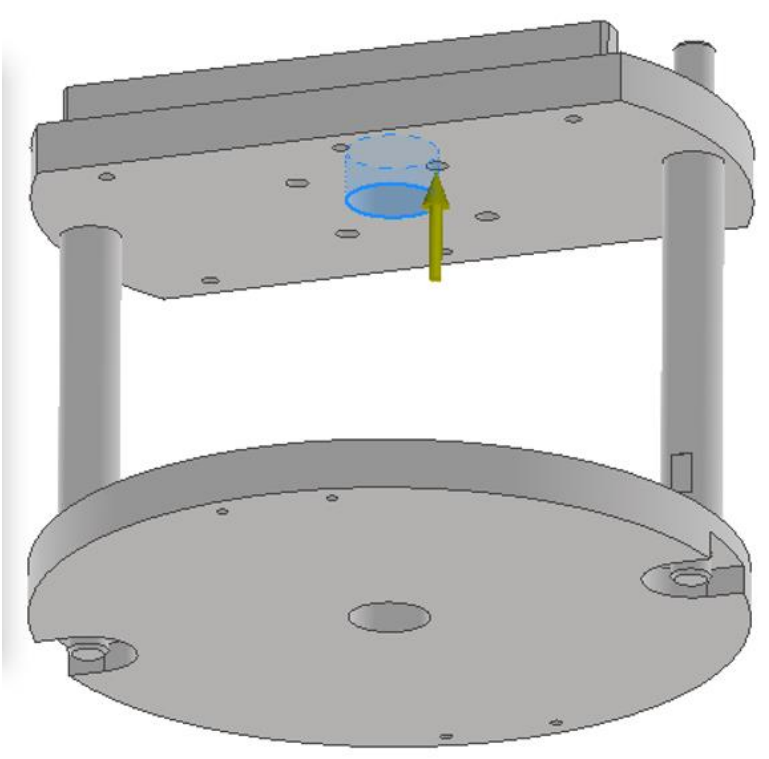

4. ábra: A keretre ható terhelőerő

A keretes prés nagyobb merevségü kereszttartóját és talapzatát két tartóoszlop köti össze, amelyek mindkét végüknél csavarkötéssel vannak rögzítve. A kereszttartó középső furatába illeszkedik a pneumatikus munkahenger központosító válla. A munkahenger csavarkötéssel van rögzítve a kereszttartóhoz. Az alsó szerszámfél a talapzaton rögzített, a felsô szerszámfél pedig a munkahenger dugattyúrúdjának végéhez.

\section{Szilárdsági ellenôrzés analitikus és végeselem módszerrel}

Az Autodesk Inventor 2019 tervezóprogram VEM funkciójával vizsgáltuk a keretszerkezet megfelelôségét a kötőgépelemek elhagyásával. A terhelő erôt a szimmetriatengely mentén, a pneumatikus munkahengernek kialakított furatban helyeztük el (4. ábra). Ahhoz, hogy a talapzat deformálódhas-

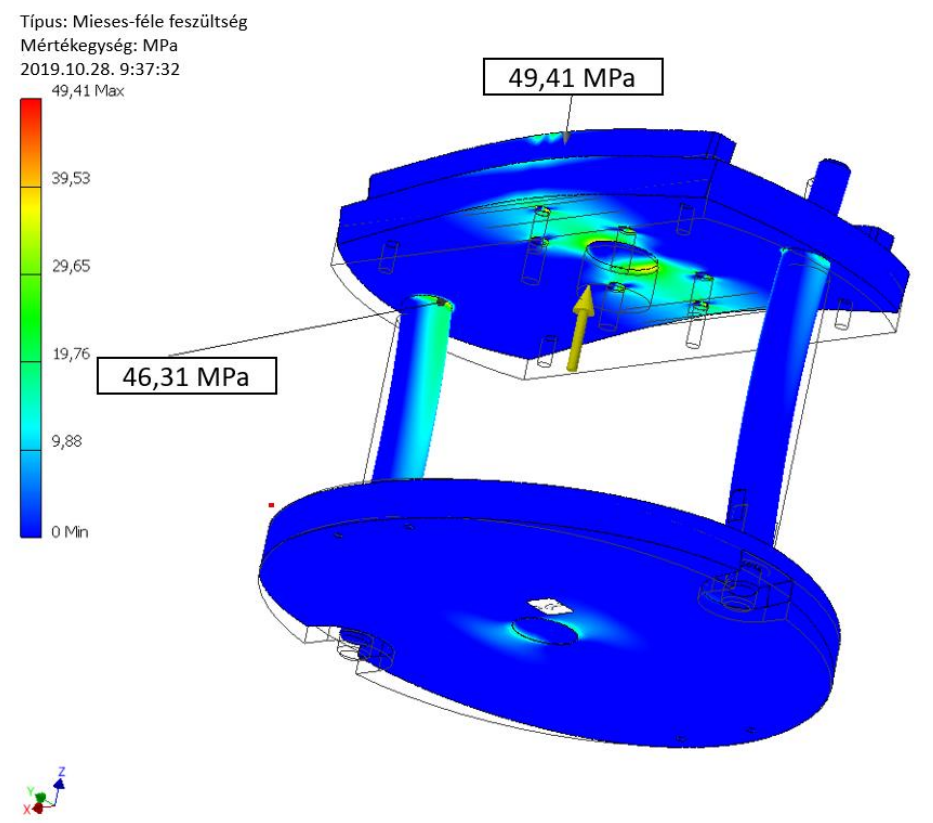

5. ábra: Keret feszültségeloszlása 
son, a megfogás az alkatrész középsô furatában történt, és itt semmiféle elmozdulást nem engedtünk meg, tehát fix megfogást definiáltunk. A hálózás az Inventor program által generált elemekkel történt. Az alkatrészek között „bonded” kapcsolatot állítottunk be, kivéve a kereszttartó és a merevítőelem között, ahol „sliding/no separation” kapcsolatot definiáltunk. A keletkezô redukált feszültség a teljes keretszerkezetben a használt anyagok folyáshatára alatti (5. ábra), tehát képes a terhelés elviselésére.

A szilárdsági ellenőrzés utolsó lépéseként végeselem módszerrel vizsgáltuk a felsô szerszámfelet, amely vizsgálatnál az elsôdleges szempont a lehajlás mértékének meghatározása volt. A szimuláció során az alkatrész felsố részén kialakított horonyban hat a 6032 N nagyságú terhelés, mely középen hajlítja meg legjobban a darabot (6(a) ábra). Az alátámasztás a préselés során a szerszámfél és az előgyártmány érintkezô felülete között lesz, így ezt a felületet láttuk el megfogási kényszerrel (6(b) ábra). A legjobban terhelt rész a megvezető csap töve, melyben $104 \mathrm{MPa}$ feszültség lép fel ( \% ábra).A feszültségeloszlás egyenletes az alkatrész felülete mentén, így egyenletes erôvel képes terhelni az eloogyártmányt. Az alkatrész C45-ös ötvözetlen acélból készül, melynek folyáshatára: $R_{e H}=340 \mathrm{MPa} . n=2$ biztonsági tényezôvel számolva a megengedett feszültség $\sigma_{\text {meg }}=170 \mathrm{MPa}$. $\mathrm{Az}$ alkatrészben fellépó maximális feszültség a megengedett alatt van $\left(\sigma<\sigma_{\mathrm{meg}}\right)$ így az alkatrész szilárdságtani szempontból megfelel.

\section{4. Összefoglalás}

A fejlesztési feladat elkészítésének célja egy olyan présgép tervezése volt, amely alkalmas mechanikai vizsgálatokhoz szükséges vizsgálati darabok gyártására, valamint a gyártásban egyes munkadarabok utómunkázására is. A szakítópróbatesteknek elegendô hely áll rendelkezésre az alsó szerszámfélben (8. ábra), ezért fó célját elérte a munka. Alfeladatként még szükséges volt megismerni a Schaeff-

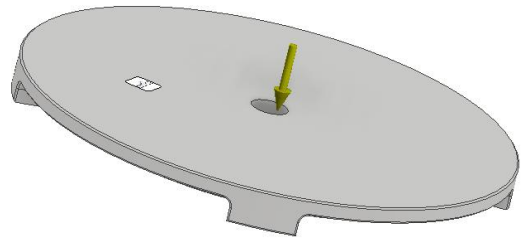

(a)

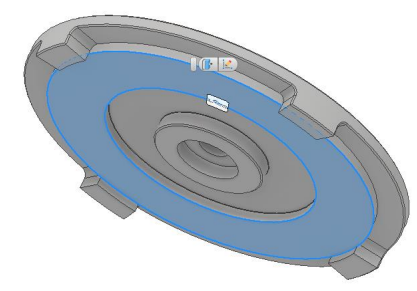

(b)

6. ábra: Felsô szerszámfélen definiált peremfeltételek: a) Terhelés, b) Rögzített felület

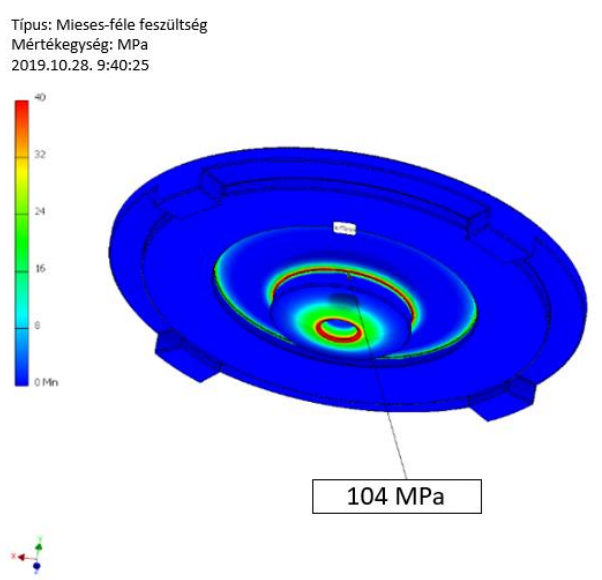

7. ábra: Felsô szerszámfél feszültségeloszlása 


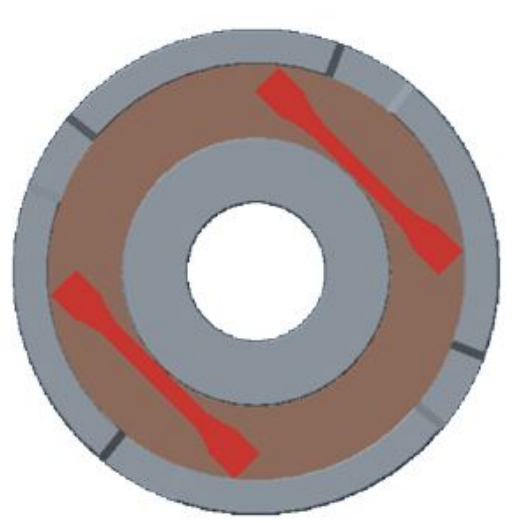

8. ábra: A szabványos szakítópróbatestek elhelyezkedése a szerszámban

ler Savaria Kft. kuplungjának múködését és felépítését, ezen kívül a kuplung egyik legfontosabb alkatrészének szokásos kialakítási módjait és gyártástechnológiáit, továbbá el kellett végezni a tervezési folyamat lépéseinek, eszközeinek és nem elhanyagolható szempontjainak összegyújtését is. Ezen alfeladatokat fóleg szakirodalmak áttekintésével tudtuk elvégezni. Ezek után számba vettük a tervezendô présgép összes elemét és azok feladatait, a megoldásváltozatok értékelése és a legjobb megoldás kiválasztása után analitikus, kézi számításokkal végzett elôtervezést követóen végeselemes program segítségével is megvizsgáltuk a szerkezet megfelelőségét. Ezek után kijelenthető, hogy a megtervezett présgép alkalmas az elôzetesen meghatározott feladatok elvégzésére.

A présgép szilárdságilag megfelel az elvárásoknak, azonban el kell látni megfeleló védôberendezésekkel, hogy biztonságos legyen a használata. További teendô még a múködtetésének biztosításához szükséges egyéb berendezések felszerelése, amelyet a vállalat erre specializálódott alkalmazottjai végeznek el.

\section{Irodalomjegyzék}

[1] Czvikovszky T., Gaál J., Nagy P., A polimertechnika alapjai, Múegyetemi Kiadó, Budapest, 2000.

[2] R. Felger, C. Spandern, M. Häßler, H.D. Elison, Innovative clutch facing materials - Cool facing for hot applications!, LuK symposium, 2006. 